\title{
«I Rhita di erebuni, nel contesto dell'arte achemenide e greco-persiana ». Parthica, 5 (2003 [2004]), pp. 9-20.
}

\section{Rémy Boucharlat}

\section{(2) OpenEdition}

1 Journals

\section{Édition électronique}

URL : http://journals.openedition.org/abstractairanica/3318

DOI : 10.4000/abstractairanica.3318

ISSN : 1961-960X

\section{Éditeur :}

CNRS (UMR 7528 Mondes iraniens et indiens), Éditions de l'IFRI

\section{Édition imprimée}

Date de publication : 15 mai 2005

ISSN : 0240-8910

\section{Référence électronique}

Rémy Boucharlat, « «I Rhita di erebuni, nel contesto dell'arte achemenide e greco-persiana ». Parthica, 5 (2003 [2004]), pp. 9-20. », Abstracta Iranica [En ligne], Volume 26 | 2005, document 106, mis en ligne le 08 décembre 2005, consulté le 25 septembre 2020. URL : http://journals.openedition.org/ abstractairanica/3318; DOI : https://doi.org/10.4000/abstractairanica.3318

Ce document a été généré automatiquement le 25 septembre 2020.

Tous droits réservés 


\section{«I Rhita di erebuni, nel contesto dell'arte achemenide e greco- persiana ». Parthica, 5 (2003 [2004]), pp. 9-20.}

\section{Rémy Boucharlat}

Article qui résume l'ouvrage publié en russe par les mêmes auteurs en 2002. Quatre rhytons en argent trouvés dans l'ancienne Erebuni, ville-forteresse de l'époque urartéenne et des siècles suivants. L'un relève en partie de l'art urartéen, deux autres de l'art aulique perse, le quatrième, par la frise représentant peut-être un banquet funèbre, de l'art gréco-perse ; il serait le plus récent de la série, fin $4^{\mathrm{e}}$-début du $3^{\mathrm{e}} \mathrm{s}$. av. J.-C. Selon les auteurs, les rhytons auraient été déposés comme offrandes dans le temple à cette époque, importante illustration de l'art arménien des $6^{{ }^{e}-5^{e}} \mathrm{~s}$., mais aussi témoin de l'art gréco-perse qui ne se limite pas à la glyptique.

\section{INDEX}

Thèmes : 3.2.2. Pré-Achéménides et Achéménides

\section{AUTEURS}

RÉMY BOUCHARLAT

CNRS - Lyon 